\title{
Research on Problems of College Students Coping With Venture Capital Yuyan Zhong ${ }^{1, a}$ Yu $\mathrm{He}^{1, b_{*}}$ \\ ${ }^{1}$ Sichuan Agricultural University, Ya'an, Sichuan, China, 625014 \\ ${ }^{\mathrm{a} e m a i l,}{ }^{\mathrm{b}}{ }^{*}$ email,
}

Keywords: College Students Venture, Funds, Investment Financing

\begin{abstract}
Students venture has got a lot of public concern and at the same time a series of drawbacks emerge gradually, college students face too large social expectations and heavy employment pressure and so on. In this paper, the current economic situation of the students start funding a systematic study to students' perspective, the current situation and existing problems through self-funding operation capability assessment, comprehensive analysis of the state of the economy, at this stage to understand the relevant policies, reasonable financing investments IV strode to study and solve the problem of college students venture funding.
\end{abstract}

\section{Introduction}

Contemporary College has a unique innovation of opinion and strong desire to start their own businesses and entrepreneurs in the circle of students have a relatively high degree of topic. Students with the latest theoretical knowledge and high-level technical superiority in the field of entrepreneurship hope place. Entrepreneurship they will find both in the country, there are many obstacles in society and prominent venture capital is a problem. In the early venture capital issue has affected the entrepreneurs, is the key on the right track. Students want to start the process to succeed, is the first to have the management capacity, financing investment capacity.

\section{The Status Quo of College Students Venture}

Venture Condition under Employment Situation. First, in recent years, more and more college students' employment situation is grim, the latest data show "of college graduates in 2016 reached 7.65 million, an increase over last year and 16 million", with a large number of returned overseas students and previous graduates stranded expected there will be more students to compete for the same jobs. 2015 annual corporate excess employment situation is not optimistic and college students will be present on the sluggish job market to withstand considerable pressure. According to the survey data show that "7.65 million graduates faced with 'structural' problems, students start willingness decline compared to 2015, businesses or become more rational."

Fortunately, however, the "Internet +" gradually occupy an important position in the field of entrepreneurship, it is a country with great potential for development of the platform, is "innovation" in the field on behalf of the term. Unlike the previous result of contemporary college students, they seek freedom, so "Internet + " model of humane management style also attracted to these college students. Financial flexibility to flow on the Internet platform, if students have a strong entrepreneurial operational capacity, not only low start-up costs, earnings also very impressive. But innovation and entrepreneurship in these areas, there are also many risks. Students' entrepreneurs cannot all be experts in the operation, no matter what business model choice, they will face difficulties and obstacles on the entrepreneurial road, even rebuffed everywhere.

State Support Entrepreneurship. In this situation, the state in order to reduce the difficulty of business students, to encourage students to think hard, think big, to alleviate the heavy social pressure on the "public entrepreneurship and innovation," introduced a number of policies, including a number of preferential policies to support entrepreneurship students. July 11 this year, Premier Li Keqiang that "economic work on the premise that scientific grasp the situation, to the 'public entrepreneurship and innovation' as the starting point to stimulate a strong vitality of the market.", While giving students a wider entrepreneurial Development Platform. By 2015, the 
national launch of "Thirteen Five-Year Plan", which includes entrepreneurial strategy, innovation-driven development strategy, it means 2016--2020 will present a diversity and openness, free competition and entrepreneurial environment [1]. Students start improving the environment, promoting economic quality and efficiency to achieve the goals of higher quality graduates start employment.

At the same time, the national implementation of entrepreneurial supply-side reform to focus on improving the quality of college students venture. Supply-side reforms are the quality and efficiency requirements, at the 2015 meeting of the Central Financial Work Leading Group, the Chairman of the Special Xi Jinping said: "In a moderate expansion of aggregate demand at the same time, focus on strengthening the supply-side structural reforms, strive to improve the quality and supply system efficiency "direction of reform which are: to meet the individual alignment future. Supply-side reform the most important areas of entrepreneurship lies in the field of education: the promotion of entrepreneurship education in priority economic and social development, improve the quality of education provision, innovation, to provide our students with quality entrepreneurship education resources [2].

Venture Capital Is Particularly Important. As seen by the business students has become a national focus of social concern, when college students ready to embark on entrepreneurial road, have to understand that business success factors, money is the key. Material determines consciousness and the economic base determines the superstructure, to start strategizing in the competition, which are the fundamental guarantee funds. Scale entrepreneurs in the process, you will find whether there is even the best programs and projects, in the absence of sufficient funds will be stranded. Sufficient funds not only represents the rich companies, but also represents the company have the ability to adjust their operations. Similarly, funding issue is not only how to obtain it, is more important is how to adjust the funds in accordance with the external environment, investment allocation, among others.

\section{The Cause of Problem on College Students Venture Capital}

Students summarize the overall problem is to get venture capital and management difficulties. Specific performance in the following areas:

College Students Lack of Related Capacity. College students are entering the community groups and there is no accumulation of entrepreneurial experience, compared with in the community for many years, entrepreneurs and low starting point, weak. At the same time, the company set up after the relative market will be loopholes in the old enterprises, project planning risk judgment on the respective national policies resilience than weak, asset management companies, financial reasonable allocation of time. These capabilities will lead to a lack of students in the venture capital is difficult to control.

Present Economic Situation Is Special. China's economy maintained steady first half of 2016, GDP grew by $6.7 \%$, it is easy to see China more than $10 \%$ from the previous high growth fell to around $7 \%$, while this year's growth rate relative to the previous year and presents economic slowdown trend, this is the new normal economic development of the situation. Economic slowdown from the surface, will make entrepreneurial college students to worry, on the one hand to obtain funds will not be affected by the state of the economy, on the other hand due to the rapidly changing economic patterns, they can break the inherent entrepreneurial thinking, according to the latest economic dynamic selection of innovative and creative business model, and after the establishment of the company, according to the changing economic structure of the future funds for effective planning, better benefits, continue to expand the scale entrepreneurship.

Banks and Other Financial Institutions Money Supply Is Weak. Relevant information "2016 China's bank financial institutions to loan loss reserves 3.47 trillion RMB, up 16.1\%," the banking sector non-performing loan ratio is rising, the bank loans tend to be more cautious. Bank of Students start the lack of strong support reasons: on the one hand, China's current financial credit system is not perfect, small-scale university student loans, the lack of effective mortgage collateral, the bank's earnings is not optimistic. These lead to many commercial bank loans for college 
students overqualified, too strict, only medium-sized enterprises tend to increase credit lines, loans for college students venture is less than normal proportion. On the other hand, since China is in the primary stage of the implementation of college students venture fund, many projects are not perfect, less entrepreneurship at all levels of government special fund, small-scale, colleges and universities are also very optimistic about the financing.

The Investment and Financing in Social Is Difficult. One is to invest in or to finance college students venture companies, will determine whether this new company has the potential to buy its stake in the availability of substantial income, accordingly, whether to provide development funding to entrepreneurs. The second is the establishment of the company after business students, when they reach a certain profit, will also consider other companies or projects for investment and financing, to improve their economic benefits to get more venture capital. But there are many significant gains on the surface, but with a significant risk of actual investment projects in the community college students in the absence of judgment, is likely to own venture capital cast in vain.

\section{College Students Venture Funding Solutions}

Students study and solve the problem of venture capital over several aspects, not only is eleven breakthrough, but also with their own business chain binding them to each other, in general the following four steps:

Self-Assessment of Financial Manipulation Force. Capital ability, clearly aware of their financial situation and income. The second venture financing capabilities, in peacetime can make reasonable adjustments for cash needs according to their own economic situation, to grasp the source and type of funds. Third, financial management capability in life is to be a reasonable use of funds in the business plan can be effective deployment of funds [3].

Students start at the same time, there are two common shortcomings: first when there is no market, consumption, financial situation analysis, blindly purchasing materials, recruit staff, buy equipment, the result will also result in the case of the profit is zero, it entrepreneurial team consumed a lot of cash flow. The second will not firm, the ideal situation is not encountered very easy to give up this industry, turn into another, which not only consumed repeatedly venture capital, will easily miss.

First Degree attractive enough to let other institutions concerned about this project, including the products can have a big market in the so-called window period after a high-yield profits can continue to go after. The second show their ability, in addition to the above mentioned financial ability to control and there is the entrepreneur's learning ability, organizational skills, stress resistance and the like. The third firm goal for the initial start for college students, is unable to do a number of areas of common development, when the founder of the financing plan described in the funds will continue to adjust, the business may change a lot deviation, but the direction to the target firm.

From the principle point of view of financial cooperation, in the future make a good control over the funds, must deal with three relationships: a first group of relations and mass, in order to prevent future financial difficulties, the need to establish a mutual fund organization, whose main members in the group between conduct, with the growth in the number, the greater the intensity of financing, mutual strength stronger. Independence and follow the lead of the second relationship, companies not only have their own set of capital allocation, while subject to state regulation, and therefore in need of appropriate trade-off relationship between the two. The third service relationship and benefits of the product to the needs of society, not the blind pursuit of profit maximization, cost-cutting over the earth, so that the quality and future development prospects will be adversely affected.

Comprehensive Analysis of the Economic Situation in the State. Because different times have different business environment, we cannot be disappointed because of economic phenomena on the surface of their own businesses. CPPCC National Committee Chairman Michael Yu, New Oriental Group, attended the end of the second session of the CPPCC National Committee, said in an interview, "I do not think China's economic slowdown will affect the entrepreneurial opportunities 
of ordinary people" in 2015. For example the United States and in the economic downturn, there are many large companies in Silicon Valley and just starting in maintaining stability, the formation of the next stage of growth momentum. China's economy is developing form of "L-based economy," economic growth turned in by the high-speed low, but this does not mean that the social entrepreneurial opportunities contain less. What is needed now is the transformation of economic development, to achieve steady growth, structural adjustment purposes, the implementation of supply-side structural reforms and the implementation of "the capacity to destocking, deleveraging, lower inventory, fill short board" of economic policies. And in recent years, it is an important period of transition, the key lies in the transformation of innovation, entrepreneurship and innovation is to keep pace. So from the point of view of economic situation, students start space does not shrink, and the degree of investment funds so long as you properly, there is considerable room for development and revenue potential.

Future economic environment is changing, retractable funds should also change. From our 2016 economic situation, economic contraction, and facing a transition structure, there is a very dramatic fluctuations in the economic cycle, which shows that this year will be a very difficult year for economic regulation. This is a successful entrepreneur or entrepreneurial students will have to understand: First, many companies will face mergers and acquisitions, or bankruptcy situation; Second, the state will cut taxes in the traditional areas, will very likely reduce VAT ; third, to the field of entrepreneurship and economic environment combined, such as per capita GDP, per capita disposable income of China's GDP change on consumer economic analysis of the situation, consumers' disposable income will directly affect the market demand; on the supply side to start the fourth, for the procurement of goods, systematically supplier, price, supply, supply risks and other basic data collection, integration and analysis, provide the basis for the digital enterprise purchasing decisions, while also meeting enterprises present and future development needs; the fifth is the capital market, it can decide whether to obtain financing to solve the shortage of funds, such as cut space is limited, profit slump, devaluation, these measures should develop a good response. Enterprises according to the economic situation needs to fund management, stable cash flow, while investing to be careful, even if the stock market rose significantly, but also to prevent cash flow broken.

Understand the Relevant Policies. 2015, the State Council promulgated the "twelve students start to enjoy the preferential policies," We understand and analysis of the project and related funds. The first is the tax incentives: "Within the annual college graduates founded individual industrial and commercial households, individual-owned enterprises, 3 years, according to 8000 RMB per household for the quota year should be deducted in turn pay various taxes and fees per year" would reduce the incentives Venture the financial cost of running, and the results will increase profits for business students have a very good incentive. The second is the venture secured loans and interest subsidies: "entrepreneurs can apply for secured credit line of 10 million, and in line with the floating three percent interest rate on a loan basis, from the financial to give discount" will be described in detail below. The third is related to waive administrative fees: "Students graduate entrepreneurship within 2 years from the date of its first registration in the business sector within 3 years, free of management class, class registration and other related administrative costs," which let the road entrepreneurial students save money and optimize the capital invested efforts.

In order to support college students venture, banking institutions in accordance with relevant state regulations, offering specialized business loans, government financial Bukui and subsidized loans for entrepreneurs, venture to provide credit support for college students: "Students graduating in line with conditions in more than six months after graduation not a job, and students registered as unemployed at the local labor and social security departments, according to their own resources and ability to repay loans obtained, and enjoy financial discount in two years." This was after graduation did not find a favorite work, the target invest in entrepreneurial college students to provide a guarantee of funds. But it is worth noting that, if the loan amount is huge, it is necessary to set clear financial plan, while family members can be a steady income as a guarantee. This policy intends to entrepreneurship students a lower threshold in such a way not only to get a loan, but also to some 
extent solves many banks are reluctant to issue loans to college students.

In addition to national policy support, and support for a number of private capital and angel investment is a representative. The so-called angel investors are through economic good personal funds to help some companies one-time initial investment period. Most of these companies are innovative technologies or innovative ideas for small project start-ups. If venture with good prospects, can be recognized by a plurality of angel investors, the amount of funds raised will be very large. But it is worth noting that, where there are many problems, prominent is asymmetric information, because most of the investment is to communicate on-line, some of the entrepreneurs in order so that he can get more money, so the information provided may be modified investors difficult to distinguish, if the violation of the relevant provisions, will end his own. Thus, college students in order to be funded through angel investors this way, we must first understand their specific requirements, a true reflection of Entrepreneurship.

Reasonable Investment Financing. The scale of social financing has grown rapidly: People's Bank of China announced the first half of 2016, social financing data, the scale in increments of 9.75 trillion RMB, an increase of $12.3 \%$. Entrepreneurial universities should understand that Social financing refers to the different areas of indirect financing through banks, but also can obtain detailed market statistics. So sharply, so that the entrepreneurial process of financing more convenient and more accurate data is obtained. The second financing needs will surge in the last three years: As the "along the way" forward, not only will the government financing needs as a driving force, a lot of private capital will enter, especially in the financial sector will be a big new business opportunities, entrepreneurship a good choice.

The first half of 2016 the rapid growth of China's foreign investment and cooperation, an increase of $58.7 \%$, especially "along the way" overseas contract business. Facing this investment boom, conditional business students can even be obtained interests in foreign investment. Second deepen the reform of investment system. As can be seen from the "on deepening reform of investment and financing of opinions" issued by the State Council, the entrepreneurs can further improve the investment management business, through innovative mechanisms to stimulate investment in the vitality and dynamism of society.

Entrepreneurs in the investment and financing usually think of a noun -P2P. P2P is defined as: "a financial point internet lending platform, need the help of e-commerce network platform to help both lenders and borrowers to establish lending relationships at the same time to complete the relevant transaction procedures," such as some time ago a very popular "e rent treasure" "Pan," and so on. But as of the end of 2016 2, P2P net loan industry has a problem with 1425 (nearly 40\%). Cause analysis of large-scale P2P problem is: from the entrepreneur's point of view, they want to raise more money but not good projects, so the implementation of the project false propaganda, claimed to have low-risk high-yield, final illegal to raise huge sums of money. From the investor's point of view, is attracted by its high-yield surface, fall into the so-called "Ponzi scheme", the proceeds with their own funds to make up for an investor. This example also for entrepreneurial college students to sound an alarm, not in order to quickly raise funds in P2P platform will own projects over the packaging to deceive investors. At the same time if you choose to invest in the P2P platform, we must guard against being fooled by some illegal products.

\section{Acknowledgements}

Fund Project: Ideological and Political Education Research of Sichuan Universities and Colleges "Research on the path of improving students' legal belief and the legal consciousness in ideological and political theory course of universities and colleges" (SZQ2014067).

Association of Social and Science Project and Political School Dual-Branch Plan of Sichuan Agricultural University "Research on Socialist Culture with Chinese Characteristic"

\section{References}

[1] Hui Shuangmin. Economic Research, Vol. 6 (2004) No 53, p.25-26 
[2] Peng Sue, Wang Yunhui, Wang Qunyong. Economic, Vol. 12 (2005) No 27, p.74-76

[3] Jing Jianfen. Education Development and Evaluation, Vol. 30 (2004) No 19, p.144-145

[4] Song Jihua. China Collective Economy, Vol. 29 (2008) No 27, p.21-23

\section{Author Introduction}

Yuyan Zhong (1995- ), Sichuan Ya 'An, the undergraduate majored in Finance of Economics College in Sichuan Agricultural University.

Yu He * (1984- ), the corresponding author, master of laws, the lecturer of Marxism College in Sichuan Agricultural University, the research direction is the Sinicization of Marxism. 